\title{
Photosynthetic Daily Light Integral during Propagation of Tecoma stans Influences Seedling Rooting and Growth
}

\author{
Ariana P. Torres and Roberto G. Lopez ${ }^{1,2}$ \\ Department of Horticulture and Landscape Architecture, Purdue University, \\ 625 Agriculture Mall Drive, West Lafayette, IN 47907
}

Additional index words. biomass accumulation, DLI, irradiance, plugs, yellow trumpet bush

\begin{abstract}
Current market trends indicate an increasing demand for unique and exotic flowering crops, including tropical plants. Tecoma stans (L. Juss. Kunth) 'Mayan Gold' is a tropical plant that was selected as a potential new greenhouse crop for its physical appearance and drought and heat tolerance. However, in winter and early spring, when propagation occurs, outdoor photosynthetic daily light integral (DLI) can be relatively low. The objective of this study was to quantify the effects of DLI during propagation of Tecoma and to determine optimum DLI levels for seed propagation. Seeds were propagated under 13 mean DLIs ranging from 0.75 to $25.2 \mathrm{~mol} \cdot \mathrm{m}^{-2} \cdot \mathrm{d}^{-1}$ created by the combination of high-pressure sodium lamps (HPS) and fixed woven shadecloths of varying densities. Thirty-five days after sowing, height, stem diameter, node number, relative leaf chlorophyll content, leaf fresh weight, leaf number, total leaf area, individual leaf area, leaf area ratio, shoot and root dry mass increased as DLI increased. Average internode elongation and specific leaf area decreased at a quadratic and linear rate, respectively, as DLI increased from 0.75 to $25.2 \mathrm{~mol} \cdot \mathrm{m}^{-2} \cdot \mathrm{d}^{-1}$. These experiments indicate that high-quality Tecoma seedlings were obtained when DLI was 14 to $16 \mathrm{~mol} \cdot \mathrm{m}^{-2} \cdot \mathrm{d}^{-1}$ during propagation.
\end{abstract}

Potted flowering plants for indoor or patio use are the second largest (17.2\%) segment of the U.S. commercial floriculture industry after the bedding plant segment (USDA, 2010). In 2009, the reported wholesale value of potted flowering plants in the top 15 producing states was $\$ 632$ million (USDA, 2010). Current market trends indicate that consumers are demanding new and unique potted flowering crops, including tropical flowering plants (Pizano, 2005). Although there is a growing market for tropical flowering plants, most northern U.S. greenhouse growers experience difficulties growing and inducing these crops to flower, mostly as a result of their energy-intensive environmental requirements (Davis and Andersen, 1989; Fausey and Cameron, 2005; Pizano, 2005). Therefore, extensive research needs to be conducted to successfully manipulate and schedule potential new floriculture crops to obtain rapid, uniform, and complete flowering (Davis and Andersen, 1989).

Received for publication 9 Sept. 2010. Accepted for publication 2 Dec. 2010.

We gratefully acknowledge Rob Eddy, Dan Hahn, and Diane Camberato for greenhouse assistance; funding from the Purdue Agriculture Research Programs Assistantship; and support from the Purdue Agricultural Experiment Station., Ball Horticultural Company, Premiere Horticulture, and The Scotts Co. for seeds, growing media, and fertilizer.

${ }^{1}$ Assistant Professor and Extension Specialist.

${ }^{2}$ To whom reprint requests should be addressed; e-mail rglopez@purdue.edu.
The exotic, unique, and unusual appearance of tropical flowering plants appeals to many flower consumers (Pizano, 2005). The yellow trumpet bush (Tecoma stans) is a tree in the Bignoniaceae family native to tropical and subtropical regions of Central and South America. It produces large funnel-shaped, bright yellow, fragrant flowers that compliment its glossy green, pinnately compound leaves. Tecoma 'Mayan Gold' was selected as a potential new annual patio flowering crop as a result of its compact nature, drought and heat tolerance, long-blooming characteristics, and few disease and pest problems (PanAmerican Seed, 2010).

Table 1. Sowing and harvest dates, mean photosynthetic photon flux $(P P F)$ provided by high-pressure sodium lamps, shadecloth percentage, mean daily light integral (DLI), and leaf and air temperatures during 5 weeks of Tecoma stans seedling propagation.

\begin{tabular}{|c|c|c|c|c|c|c|}
\hline \multirow[b]{2}{*}{ Sowing date } & \multirow[b]{2}{*}{ Harvest date } & \multirow{2}{*}{$\begin{array}{c}P P F \\
\left(\mu \mathrm{mol} \cdot \mathrm{m}^{-2} \cdot \mathrm{s}^{-1}\right)\end{array}$} & \multirow{2}{*}{$\begin{array}{l}\text { Shade } \\
(\%)\end{array}$} & \multirow{2}{*}{$\begin{array}{c}\text { DLI } \\
\left(\mathrm{mol} \cdot \mathrm{m}^{-2} \cdot \mathrm{d}^{-1}\right)\end{array}$} & \multicolumn{2}{|c|}{ Temperature $\left({ }^{\circ} \mathrm{C}\right)$} \\
\hline & & & & & Air & Leaf \\
\hline 15 Jan. 2010 & 21 Feb. 2010 & $2.0 \pm 1.0$ & 70 & $0.8 \pm 0.6$ & $22.7 \pm 0.3$ & $21.6 \pm 1.7$ \\
\hline 15 Jan. 2010 & 21 Feb. 2010 & $2.0 \pm 1.6$ & 30 & $2.8 \pm 1.1$ & $22.3 \pm 0.2$ & $19.9 \pm 1.8$ \\
\hline 15 Jan. 2010 & 21 Feb. 2010 & $4.0 \pm 1.2$ & 50 & $5.3 \pm 1.6$ & $22.6 \pm 0.2$ & $\mathrm{ND}^{\mathrm{y}}$ \\
\hline 13 Feb. 2009 & 30 Mar. 2009 & $10.0 \pm 2.9$ & 50 & $5.8 \pm 2.6$ & $22.2 \pm 0.7$ & $22.5 \pm 2.5$ \\
\hline 15 Jan. 2010 & 21 Feb. 2010 & $35.0 \pm 4.2$ & $\mathrm{NA}^{\mathrm{z}}$ & $6.5 \pm 2.0$ & $22.7 \pm 0.2$ & $19.1 \pm 2.7$ \\
\hline 13 Feb. 2009 & 30 Mar. 2009 & $60.0 \pm 7.5$ & 70 & $9.9 \pm 3.3$ & $23.4 \pm 0.7$ & ND \\
\hline 23 Jun. 2009 & 20 Jul. 2009 & $48.0 \pm 7.0$ & NA & $11.1 \pm 1.9$ & $24.8 \pm 1.5$ & $23.2 \pm 3.4$ \\
\hline 13 Feb. 2009 & 30 Mar. 2009 & $72.0 \pm 10.1$ & 30 & $15.3 \pm 2.0$ & $23.5 \pm 0.7$ & ND \\
\hline 13 Feb. 2009 & 30 Mar. 2009 & $80.0 \pm 9.6$ & NA & $15.6 \pm 1.9$ & $23.3 \pm 0.9$ & $23.7 \pm 3.1$ \\
\hline 23 Jun. 2009 & 20 Jul. 2009 & $78.0 \pm 6.1$ & 30 & $16.0 \pm 3.5$ & $25.3 \pm 1.6$ & ND \\
\hline 13 Feb. 2009 & 30 Mar. 2009 & $112.0 \pm 8.8$ & NA & $21.3 \pm 4.0$ & $23.5 \pm 0.5$ & $23.6 \pm 3.2$ \\
\hline 23 Jun. 2009 & 20 Jul. 2009 & $109.0 \pm 8.3$ & 30 & $22.0 \pm 5.2$ & $23.3 \pm 1.3$ & $28.1 \pm 3.6$ \\
\hline 23 Jun. 2009 & 20 Jul. 2009 & $111.0 \pm 8.0$ & NA & $25.2 \pm 5.9$ & $24.2 \pm 1.2$ & $27.4 \pm 6.7$ \\
\hline
\end{tabular}

${ }^{\mathrm{z}} \mathrm{NA}=$ no shade curtain was used.

${ }^{\mathrm{y}} \mathrm{ND}=$ no data collected.
Most potted flowering plants are vegetatively propagated by shoot-tip cuttings; however, a few are propagated from seed. The propagation success of seedlings requires an understanding of the effects of irradiance [photosynthetically active radiation (PAR) or photosynthetic photon flux $(P P F)]$ and temperature to manipulate plant growth and development (Fausey and Cameron, 2005). Some desired characteristics of floriculture seedlings and plugs are increased biomass (shoot and root), compactness (reduced internode elongation and proportional height), and adequate leaf area to promote growth and development after propagation (Faust et al., 2005; Lopez and Runkle, 2008; Pramuk and Runkle, 2005; Styer and Koranski, 1997).

Photosynthetic DLI is an important environmental parameter closely related to growth and quality of greenhouse-grown crops. In the northern part of the United States during winter and early spring, when most propagation occurs, outdoor DLI ranges from 5 to $10 \mathrm{~mol} \cdot \mathrm{m}^{-2} \cdot \mathrm{d}^{-1}$ (Korczynski et al., 2002). Furthermore, outdoor DLI levels can be reduced by up to $50 \%$ or more by shading from greenhouse glazing, thermal energy curtains, structures, obstructions, and hanging baskets, resulting in DLI as low as 1 to $5 \mathrm{~mol} \cdot \mathrm{m}^{-2} \cdot \mathrm{d}^{-1}$, which can be further reduced during extended periods of cloudy weather (Lopez and Runkle, 2008).

DLI recommendations for most floriculture crops are to provide $\approx 4$ to $6 \mathrm{~mol} \cdot \mathrm{m}^{-2} \cdot \mathrm{d}^{-1}$ with a $P P F$ between 100 and $200 \mu \mathrm{mol} \cdot \mathrm{m}^{-2} \cdot \mathrm{s}^{-1}$ during propagation under a $12-\mathrm{h}$ photoperiod during the first stage of root initiation. Subsequently, commercial growers should increase DLI to $\approx 6$ to $8 \mathrm{~mol} \cdot \mathrm{m}^{-2} \cdot \mathrm{d}^{-1}$ (PPF between 200 and $400 \mu \mathrm{mol} \cdot \mathrm{m}^{-2} \cdot \mathrm{s}^{-1}$ under a $12-\mathrm{h}$ photoperiod) to promote fully rooted cuttings and optimal shoot and root biomass accumulation (Dole and Hamrick, 2006; Lopez and Runkle, 2008). Pramuk and Runkle (2005) suggest that supplemental lighting can greatly increase quality and reduce subsequent time to flower when natural DLI levels are low (e.g., less than $\left.8 \mathrm{~mol} \cdot \mathrm{m}^{-2} \cdot \mathrm{d}^{-1}\right)$. Thus, when natural irradiance falls below optimum levels, high-intensity discharge (HID) lighting should be used in commercial greenhouses to increase DLI. 
As DLI increases, photosynthetic rates consequently increase (Donelly and Fisher, 2002; Holcomb and Berghage, 2001; Klopmeyer et al., 2003) contributing to faster rooting, biomass accumulation, compactness, subsequent flowering, and overall quality. For example, baby's breath (Gypsophila paniculata L. 'Perfecta') cuttings propagated under a DLI of $12 \mathrm{~mol} \cdot \mathrm{m}^{-2} \cdot \mathrm{d}^{-1}$ rooted twice as fast as cuttings grown under a DLI of $7 \mathrm{~mol} \cdot \mathrm{m}^{-2} \cdot \mathrm{d}^{-1}$ (Islam and Willumsen, 2001). Lopez and Runkle (2008) reported that rooting, biomass accumulation, and quality of New Guinea impatiens (Impatiens hawkeri Bull.) and petunia (Petunia $\times$ hybrida hort. Vilm.-Andr.) cuttings increased as mean propagation DLI increased from 1.2 to $7.5 \mathrm{~mol} \cdot \mathrm{m}^{-2} \cdot \mathrm{d}^{-1}$. For example, root number of petunia 'Tiny Tunia Violet Ice' after $16 \mathrm{~d}$ of propagation increased from 17 to 40 , whereas cutting shoot height decreased from 6.3 to $4.5 \mathrm{~cm}$, and root and shoot dry biomass increased by $737 \%$ and $106 \%$ for plants rooted under 1.2 and 7.5 $\mathrm{mol} \cdot \mathrm{m}^{-2} \cdot \mathrm{d}^{-1}$, respectively. Similarly, shoot dry weight per internode for celosia 'Gloria Mix' (Celosia argentea var. plumose L.), seed impatiens 'Accent Red' (Impatiens wallerana Hook.), marigold 'Bonanza Yellow' (Tagetes patula L.), and pansy 'Crystal Bowl Yellow' (Viola ×wittrockiana Gams.) increased linearly as DLI increased from 4.1 to $14.2 \mathrm{~mol} \cdot \mathrm{m}^{-2} \cdot \mathrm{d}^{-1}$. In addition, seedling became more compact as DLI increased in celosia, seed impatiens, and salvia (Salvia splendens Sell ex Roem. \& Schult.) (Pramuk and Runkle, 2005).

To our knowledge, no studies have been published on the effects of DLI during Tecoma seed propagation. The objectives of this study were 1) to quantify how the mean DLI during propagation influences rooting, growth, and quality of Tecoma seedlings; and 2) to determine optimum DLI levels for propagation of high-quality seedlings.

\section{Materials and Methods}

Plant material and culture. Seeds of Tecoma stans 'Mayan Gold' (PanAmerican Seed, West Chicago, IL) were sown in eight 72-cell $(44 \mathrm{~mL})$ plug trays (Dillen Products, Middlefield, $\mathrm{OH})$ filled with a commercial soilless medium composed of $\approx 70 \%$ Canadian sphagnum peatmoss and $\approx 30 \%$ perlite (Super Fine Germinating Mix; Conrad Fafard, Anderson, SC). Seeds were covered with a thin layer of vermiculite (Sunshine; SunGro Horticulture, Bellevue, WA) to maintain moisture and were irrigated as necessary with acidified water supplemented with water-soluble fertilizer to provide the following $\left(\mathrm{mg} \cdot \mathrm{L}^{-1}\right): 100$ nitrogen, 15 phosphorus, 84 potassium, 34 calcium, 14 magnesium, 0.5 iron, 0.25 manganese and zinc, 0.13 boron and copper, and 0.05 molybdenum (Peters Excel $\subset$ Cal-Mag $\odot$ 15N-2.2P-12.5K; The Scotts Co., Marysville, $\mathrm{OH})$ beginning at sowing. Trays were covered with clear plastic germination lids (Dillen Products, Middlefield, $\mathrm{OH}$ ) to increase relative humidity and were removed on Day 10 to allow air circulation.
Propagation environment. Tecoma seeds were sown on 13 Feb. 2009, 23 June 2009, and 15 Jan. 2010 in a glass-glazed greenhouse

with exhaust fan and evaporative-pad cooling, radiant hot water heating, and retractable shade curtains controlled by an environmental

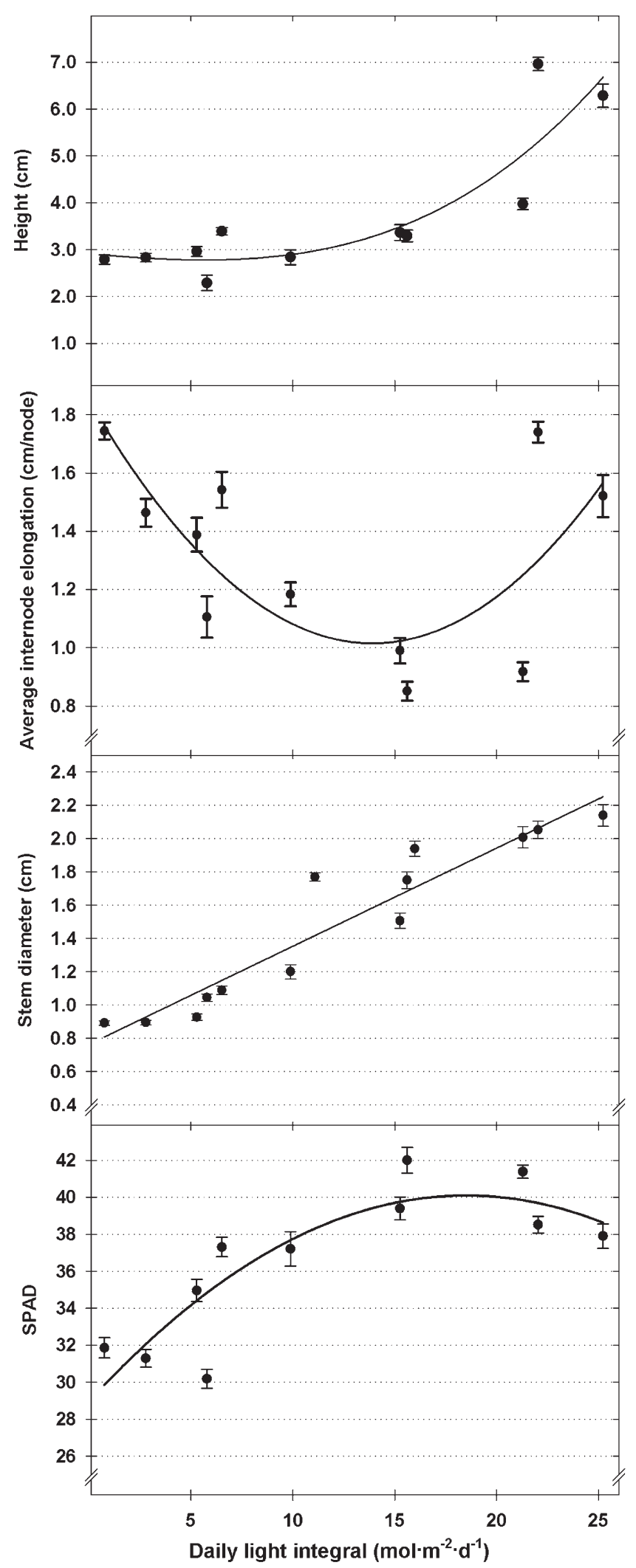

Fig. 1. (A-D) Relationships between mean daily light integral and height, average internode elongation, stem diameter, and relative leaf chlorophyll content measured after $35 \mathrm{~d}$ of propagation for Tecoma seedlings. Each symbol represents the mean of 15 seedlings, and error bars represent SE of the mean. Regression lines are represented with corresponding $R^{2}$. ${ }^{* *}$ Significant at $P \leq 0.001$. 
computer (Maximizer Precision 10; Priva Computers Inc., Vineland Station, Ontario, Canada) at Purdue University, West Lafayette, IN (lat. $40^{\circ} \mathrm{N}$ ). The greenhouse air temperature set point was $23{ }^{\circ} \mathrm{C}$. A 16 -h photoperiod (0500 to $2100 \mathrm{HR}$ ) was maintained with natural daylengths and day-extension lighting provided from HPS lamps (e-system HID; PARsource, Petaluma, CA). An automatic woven shade curtain that reduced light by $\approx 50 \%$ was retracted when the outdoor light intensity reached $\approx 1000 \mu \mathrm{mol} \cdot \mathrm{m}^{-2} \cdot \mathrm{s}^{-1}$ (OLS 50; Ludvig Svensson Inc., Charlotte, NC) throughout the study to prevent leaf scorch.

Thirteen DLI treatments were created in the propagation environment with the combination of HPS lamps that provided a supplemental $P P F$ for $16 \mathrm{~h}$ [as measured with a line quantum sensor containing 10 photodiodes (Apogee Instruments, Inc., Logan, UT)] and fixed woven shadecloths placed above individual propagation compartments that reduced light by $\approx 30 \%, 50 \%$, or $70 \%$ (DeWitt Company, Sikeston, MO) (Table 1). Air temperature and light intensity were measured at 20-s intervals with an enclosed thermocouple and quantum sensor (WatchDog weather station; Spectrum Technologies, Plainfield, IL, and LI-COR, Lincoln, NE) positioned in the center of each treatment. Leaf temperature was measured at 5-min intervals with an infrared temperature sensor (Temperature/ Transmitter Model OS136-1; Omega Engineering Inc., Stamford, CT) connected to a data logger. The mean leaf and air temperature and DLI were calculated for each treatment and repetition (Table 1).

Effects of daily light integral on propagation. Fifteen seedlings per DLI treatment were randomly selected from 144 seedlings and harvested 5 weeks after sowing. Height, number of nodes and leaves, stem diameter measured directly below the cotyledon, and total leaf area were measured at harvest. The rooting medium was carefully washed off; roots, leaves, and stems were separated; and shoot dry weight (SDW) and root dry weight (RDW) were recorded after drying in a forced-air oven at $70{ }^{\circ} \mathrm{C}$ for 1 week. In addition, leaf fresh weight was recorded for each seedling for Repetitions 2 and 3. Rootto-shoot dry weight ratio (R:S ratio) and specific leaf area (SLA) were determined as the relation between the total leaf area and the total leaf fresh weight, being directly correlated with biomass allocation to leaves. Leaf area ratio (LAR) was calculated as total leaf area divided by total dry weight, representing the amount of biomass located in a certain leaf area (Lambers et al., 2008). Relative leaf chlorophyll content was measured on 30 Mar. 2009, 20 July 2009, and 21 Feb. 2010 for Repetitions 1, 2, and 3, respectively, using a chlorophyll meter (SPAD-502, SoilPlant Analysis Development; Konica Minolta, Tokyo, Japan) by averaging the reading of three leaves on each of the 15 plants per treatment.

Data analysis. DLI treatments were randomized between propagation dates within the greenhouse. Data were analyzed using the SAS (SAS Institute, Cary, NC) means procedure (PROC MEANS) for analysis of simple

statistics. Regression analysis was performed using Sigma Plot 11.0 (Systat Software, Inc., San Jose, CA).

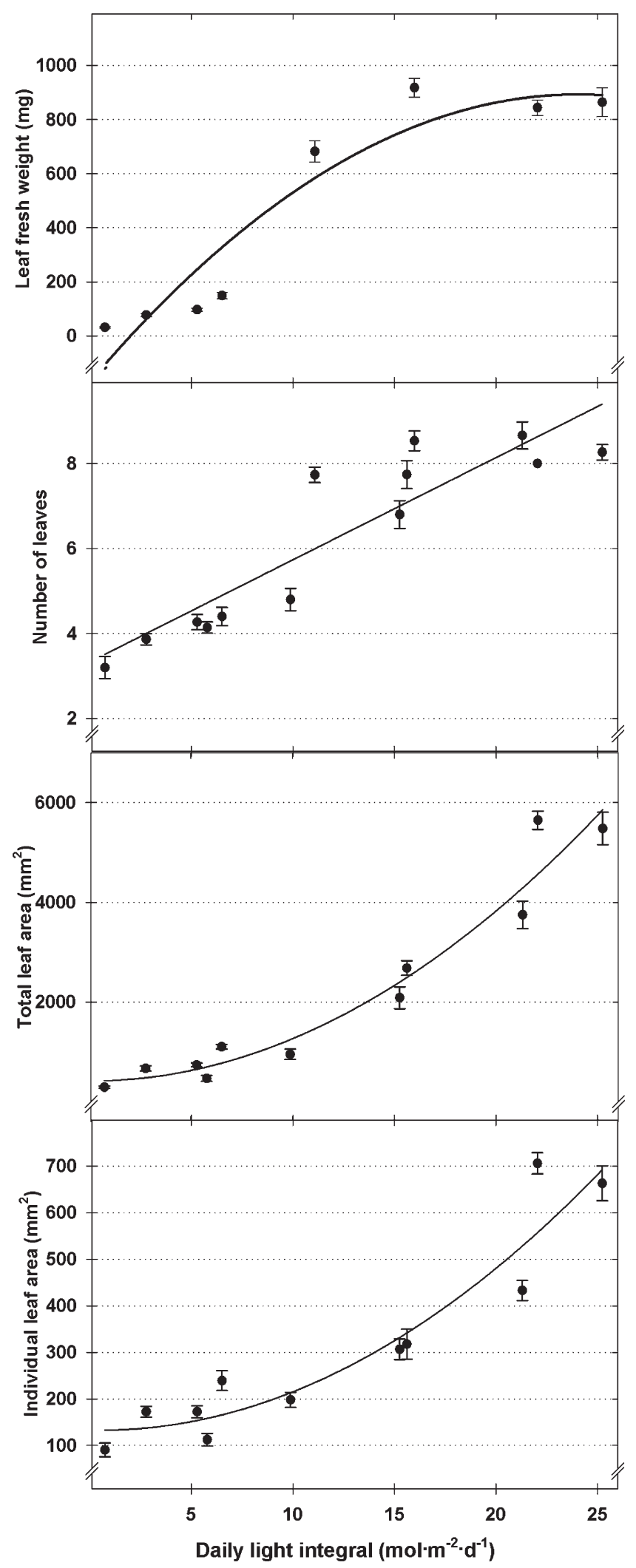

Fig. 2. (A-D) Relationships between mean daily light integral and leaf fresh weight, leaf number, total leaf area, and average individual leaf area measured after $35 \mathrm{~d}$ of propagation for Tecoma seedlings. Each symbol represents the mean of 15 seedlings, and error bars represent SE of the mean. Regression lines are represented with corresponding $R^{2}$.***Significant at $P \leq 0.001$. 


\section{Results}

As DLI increased from 0.75 to 25.2 $\mathrm{mol} \cdot \mathrm{m}^{-2} \cdot \mathrm{d}^{-1}$, height of seedlings after $35 \mathrm{~d}$ of propagation increased from 2.8 to $6.3 \mathrm{~cm}$ (125\%) (Fig. 1A). Node number increased from 1.6 to 4.3 as DLI increased (data not shown). Average internode elongation exhibited a quadratic decrease from 1.7 to $0.9 \mathrm{~cm} /$ node as propagation DLI increased (Fig. 1B). Stem diameter of seedlings after $35 \mathrm{~d}$ of propagation increased linearly from 0.9 to $2.1 \mathrm{~mm}$ as DLI increased from 0.75 to $25.2 \mathrm{~mol} \cdot \mathrm{m}^{-2} \cdot \mathrm{d}^{-1}$ (Fig. 1C). Relative leaf chlorophyll content increased from 31.3 to 42.0 as DLI increased from 0.75 to $15.6 \mathrm{~mol} \cdot \mathrm{m}^{-2} \cdot \mathrm{d}^{-1}$ (Fig. 1D).

Leaf fresh weight from the beginning of propagation increased from 31.3 to $863.6 \mathrm{mg}$ as DLI increased from 0.75 to $25.2 \mathrm{~mol} \cdot \mathrm{m}^{-2} \cdot \mathrm{d}^{-1}$ (Fig. 2A). Leaf number increased linearly from 3.2 to $8.3(159 \%)$ and total leaf area and average individual leaf area when measured after $35 \mathrm{~d}$ of propagation increased at a quadratic rate, respectively, as DLI increased (Fig. 2B-D). SLA decreased linearly from 9.2 to $6.3 \mathrm{~mm}^{2} / \mathrm{mg}(32 \%)$ as mean propagation DLI increased from 0.75 to $25.2 \mathrm{~mol} \cdot \mathrm{m}^{-2} \cdot \mathrm{d}^{-1}$ (Fig. 3A). LAR increased from 18.8 to $38.1 \mathrm{~mm}^{2} / \mathrm{mg}$ as DLI during propagation increased from 0.75 to $22.0 \mathrm{~mol} \cdot \mathrm{m}^{-2} \cdot \mathrm{d}^{-1}$ (Fig. 3B). The relationship between SDW, RDW, or R:S ratio (data not presented) and DLI was quadratic as DLI increased from 0.75 to $25.2 \mathrm{~mol} \cdot \mathrm{m}^{-2} \cdot \mathrm{d}^{-1}$ during propagation (Fig. 3C-D). For example, when DLI increased from 0.75 to $25.2 \mathrm{~mol} \cdot \mathrm{m}^{-2} \cdot \mathrm{d}^{-1}$, RDW increased by $107.5 \mathrm{mg}$ (2388\%).

\section{Discussion}

Routine monitoring and management of DLI during seed propagation can lead to successful and profitable production of transplants that are proportionally compact (i.e., reduced internode elongation and height) and fully rooted. This and previous studies have shown that as DLI increases, shoot and root dry weight, stem diameter, leaf area, plug pullability, root number, and dry mass in seedlings and cutting transplants increase (Islam and Willumsen, 2001; Lopez and Runkle, 2008; Pramuk and Runkle, 2005; Wook et al., 2009).

Commercial greenhouse growers consider compactness (reduced internode elongation), adequate biomass per internode, and thick stems as indicators of high-quality seedlings (Pramuk and Runkle, 2005). Additionally, compact and fully rooted transplants with adequate leaf area and biomass facilitate shipping and ensure successful transplanting (Pramuk and Runkle, 2005). The most commercially acceptable seedlings in this study, exemplified by root-to-shoot biomass accumulation, height, and average internode elongation, were obtained when DLI was $\approx 14$ to $16 \mathrm{~mol} \cdot \mathrm{m}^{-2} \cdot \mathrm{d}^{-1}$. DLI levels less than 14 $\mathrm{mol} \cdot \mathrm{m}^{-2} \cdot \mathrm{d}^{-1}$ resulted in delayed rooting and excessive internode elongation. However, under high DLI (16 $\mathrm{mol} \cdot \mathrm{m}^{-2} \cdot \mathrm{d}^{-1}$ or higher), internode elongation began to increase as a result of a greater difference between the day and night temperatures (Table 1).

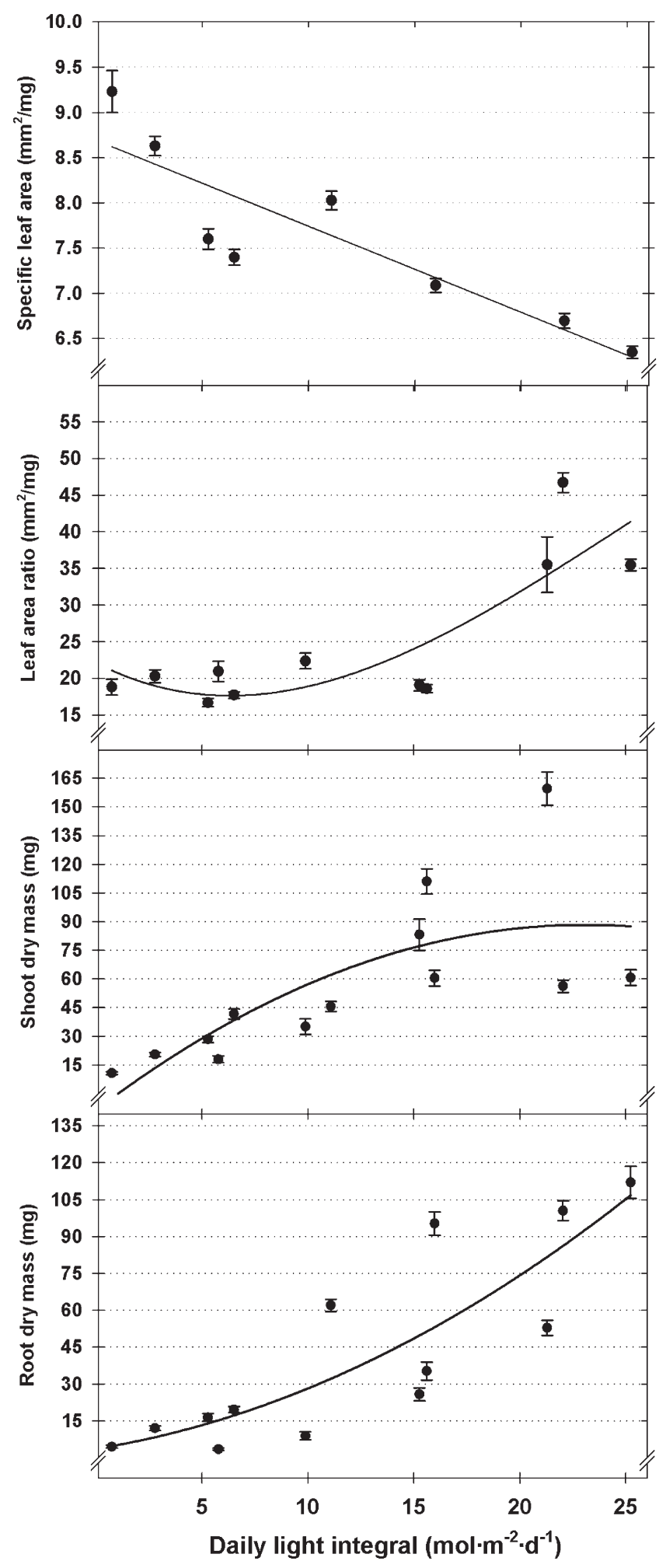

Fig. 3. (A-D) Relationships between mean daily light integral and specific leaf area, leaf area ratio, shoot dry weight, and root dry weight after $35 \mathrm{~d}$ of propagation for Tecoma seedlings. Each symbol represents the mean of 15 seedlings, and error bars represent SE of the mean. Regression lines are represented with corresponding $R^{2}$.*** Significant at $P \leq 0.001$.

As the mean propagation DLI increased from 0.75 to $25.2 \mathrm{~mol} \cdot \mathrm{m}^{-2} \cdot \mathrm{d}^{-1}$, height of Tecoma seedlings increased from 2.9 to $6.3 \mathrm{~cm}$. This increase in height, combined with other parameters (biomass accumulation and allocation and internode elongation), also improved when DLI increased, resulting in fully developed and proportional seedlings. These results are consistent with the findings of Pramuk and Runkle (2005), who reported that as propagation DLI increased from 4.1 to $14.2 \mathrm{~mol} \cdot \mathrm{m}^{-2} \cdot \mathrm{d}^{-1}$, height of marigold and celosia increased by $10 \%$ and $12 \%$, respectively. However, in the same study, seedling 
height of impatiens and salvia decreased by $27 \%$ and $37 \%$, respectively. Similarly, Faust et al. (2005) found no consistent relationship of DLI and height across several bedding plants [ageratum (Ageratum houstonianum L.), marigold (Tagetes erecta L.), petunia, salvia (Salvia coccinea L.), vinca (Catharantus roseus L.), and zinnia (Zinnia elegans L.)].

After $35 \mathrm{~d}$ of propagation, relative leaf chlorophyll content was obtained to confirm uniform appearance and to identify if any chlorosis was present in seedlings as a result of different DLI levels. Relative leaf chlorophyll content increased by 10.2 SPAD units as mean DLI increased during propagation, reaching its maximum of $42.0 \mathrm{SPAD}$ units at $15.6 \mathrm{~mol} \cdot \mathrm{m}^{-2} \cdot \mathrm{d}^{-1}$. However, Nemali and van Iersel (2004) found that as DLI increased from 5.3 to $19.4 \mathrm{~mol} \cdot \mathrm{m}^{-2} \cdot \mathrm{d}^{-1}$, SPAD values of shade-tolerant wax begonias (Begonia semperflorens-cultorum Hort.) decreased. Nonetheless, all the SPAD values among treatments were within the range for healthy plants, and we did not observe chlorosis or deficiencies among treatments (personal observation).

As propagation DLI increased from 0.75 to $22.0 \mathrm{~mol} \cdot \mathrm{m}^{-2} \cdot \mathrm{d}^{-1}$, LAR increased by 27.9 $\mathrm{mm}^{2} / \mathrm{mg}$. Similar results were obtained by Faust et al. (2005) for ageratum, marigold, petunia, salvia, vinca, and zinnia, in which leaf area per gram of plant dry mass decreased as DLI increased. Conversely, Nemali and van Iersel (2004) did not find any correlation between DLI and LAR in wax begonia. In a study of 24 wild species, LAR was found to be highly correlated with growth rate (Poorter and Remkes, 1990). According to Poorter and Remkes (1990), plants with a higher LAR have an increased carbon gain (growth rate) that results from a higher investment in leaf area.

SLA decreased linearly by $2.9 \mathrm{~mm}^{2} / \mathrm{mg}$ as propagation DLI increased from 0.75 to 25.2 $\mathrm{mol} \cdot \mathrm{m}^{-2} \cdot \mathrm{d}^{-1}$. Because SLA was obtained by dividing total leaf area by total leaf fresh weight, when SLA decreases, biomass accumulation per unit of leaf area increases. Thus, as SLA decreases, leaf thickness increases by the increase in biomass accumulation by leaves (Poorter and Nagel, 2000). These findings indicate that Tecoma seedlings propagated under higher DLIs developed thicker leaves that can be associated with a higher photosynthetic capacity (Reich et al., 1998).

During propagation, root and shoot biomass accumulation are strongly correlated with DLI received at the plant canopy if the propagules are under no water or nutrient stress (Nemali and van Iersel, 2004). For Tecoma seedlings, as the mean DLI increased during propagation, SDW, RDW, and R:S ratio increased at quadratic rates indicating the seedlings were not under environmental or cultural stresses (Fig. 3C-D). Rooting of seedlings (i.e., root biomass accumulation) was enhanced by increasing propagation DLI. However, SDW reached its maximum at $21.3 \mathrm{~mol} \cdot \mathrm{m}^{-2} \cdot \mathrm{d}^{-1}$ and began to level off above this level. Nonetheless, R:S ratio increased by $339 \%$ when DLI increased from 0.75 to $25.2 \mathrm{~mol} \cdot \mathrm{m}^{-2} \cdot \mathrm{d}^{-1}$ (data not shown). An increase in $\mathrm{R}: \mathrm{S}$ ratio indicates that plants were acclimated to produce a larger leaf area under higher PPF (Harris, 1992; Nemali and van Iersel, 2004). Similarly, R:S ratio of New Guinea impatiens and petunia increased as propagation DLI increased from 1.3 to 6.1 $\mathrm{mol} \cdot \mathrm{m}^{-2} \cdot \mathrm{d}^{-1}$ (Lopez and Runkle, 2008). However, R:S ratio in wax begonia was unaffected by an increase of DLI from 5.3 to 19.4 $\mathrm{mol} \cdot \mathrm{m}^{-2} \cdot \mathrm{d}^{-1}$ (Nemali and van Iersel, 2004).

Photosynthetic DLI requirements depend on species. Moe (1994) categorized five classes of crops by their post-propagation DLI requirements: 5 to $10 \mathrm{~mol} \cdot \mathrm{m}^{-2} \cdot \mathrm{d}^{-1}$ for lowlight crops, 10 to $20 \mathrm{~mol} \cdot \mathrm{m}^{-2} \cdot \mathrm{d}^{-1}$ for mediumlight crops, 20 to $30 \mathrm{~mol} \cdot \mathrm{m}^{-2} \cdot \mathrm{d}^{-1}$ for high-light crops, and greater than $30 \mathrm{~mol} \cdot \mathrm{m}^{-2} \cdot \mathrm{d}^{-1}$ for very-high-light crops. However, few, if any, studies have categorized crops by their propagation DLI requirements. Our findings indicate that Tecoma seedlings can be classified as a high-light crop during propagation, because its morphological and physical characteristics were optimum when propagation DLI was maintained between 14 and $16 \mathrm{~mol} \cdot \mathrm{m}^{-2} \cdot \mathrm{d}^{-1}$. At light levels below the species-specific light compensation point, plants experience little or no root growth and development. Providing irradiance below the light compensation point can lead to delayed or failed rooting in greenhouse crops (Lopez, 2007).

This study illustrates the effects of propagating Tecoma seedlings under a wide range of low DLIs commonly observed in northern latitudes during late winter and early spring when propagation is likely to occur. Growers can increase propagation DLI with supplemental HID lamps to improve growth, rooting, development, and overall quality. In addition, we observed a decreased incidence of powdery mildew when DLI was greater than $4 \mathrm{~mol} \cdot \mathrm{m}^{-2} \cdot \mathrm{d}^{-1}$.

Further research is necessary to determine how the interaction of different DLI levels during propagation and finishing influence growth and development of Tecoma plants. Additionally, the interaction of DLI, temperature, plant growth regulators, and photoperiod needs to be addressed to ensure high-quality flowering plants.

\section{Literature Cited}

Davis, T.D. and A.S. Andersen. 1989. Growth retardants as aids in adapting new floricultural crops to pot culture. Acta Hort. 252:77-86.

Dole, J.M. and D.J. Hamrick. 2006. Propagation basics, p. 3-16. In: Dole, J. and J. Gibson (eds.). Cutting propagation: A guide to propagating and producing floriculture crops. Ball Publishing, Batavia, IL.

Donelly, C.S. and P.R. Fisher. 2002. High-pressure sodium lighting affects greenhouse production of vegetative cuttings for specialty annuals. HortScience 37:623-626.

Fausey, B.A. and A.C. Cameron. 2005. Evaluating herbaceous perennial species as new flowering potted crops. Acta Hort. 683:207-213.

Faust, J.E., V. Holcombe, N.C. Rajapakse, and D.R. Layne. 2005. The effect of daily light integral on bedding plant growth and flowering. HortScience 40:645-649.

Harris, R.W. 1992. Root-to-shoot ratios. J. Arboriculture 18:39-42.
Holcomb, E.J. and R. Berghage. 2001. Photoperiod, chilling and light quality during daylight extension affect growth and flowering of tissuecultured Easter lily plants. HortScience 36:5355.

Islam, N. and K. Willumsen. 2001. Effects of photoperiod and daily light integral on rooting, subsequent growth, flowering and yield of flowering stems in Gypsophila paniculata L. 'Perfecta'. Gartenbauwissenschaft 66:225228.

Klopmeyer, M., M. Wilson, and C.A. Whealy. 2003. Propagating seed crops, p. 165-180. In: Hamrick, D. (ed.). Ball redbook: Crop production. 17th Ed., Vol. 2. Ball Publishing, Batavia, IL.

Korczynski, P.C., J. Logan, and J.E. Faust. 2002. Mapping monthly distribution of daily light integrals across the contiguous United States. HortTechnology 12:12-16.

Lambers, H., F.S. Chapin III, and R.L. Pons. 2008. Plant physiological ecology. 2nd Ed. Springer, New York, NY.

Lopez, R.G. 2007. Stock plant and propagation photosynthetic daily light integral and storage influences postharvest performance of herbaceous cuttings. PhD Diss., Dept. of Horticulture, Michigan State Univ., East Lansing, MI.

Lopez, R.G. and E.S. Runkle. 2008. Photosynthetic daily light integral during propagation influences rooting and growth of cuttings and subsequent development of New Guinea impatiens and petunia. HortScience 43:2052-2059.

Moe, R. 1994. Vekstfysiologiske aspekter med høege beysningsstyrker. Gartneryrket 84:8-13.

Nemali, K.S. and M.W. van Iersel. 2004. Light effects on wax begonia: Photosynthesis, growth respiration, maintenance respiration, and carbon use efficiency. J. Amer. Soc. Hort. Sci. 129: 416-424.

PanAmerican Seed. 2010. Grower facts: Tecoma Mayan Gold. Ball Horticultural Company. 15 June 2010. <http://www.panamseed.com/plant_ info. aspx?phid $=084100001021159>$.

Pizano, M. 2005. International market trendsTropical flowers. Acta Hort. 683:79-86.

Poorter, H. and O. Nagel. 2000. The role of biomass allocation in the growth response of plants to different levels of light, $\mathrm{CO}_{2}$, nutrients and water: A quantitative review. Aust. J. Plant Physiol. 27:595-607.

Poorter, H. and C. Remkes. 1990. Leaf area ratio and net assimilation rate of 24 wild species differing in relative growth rate. Oecologia 83: 553-559.

Pramuk, L.A. and E.S. Runkle. 2005. Photosynthetic daily light integral during the seedling stage influences subsequent growth and flowering of Celosia, Impatiens, Salvia, Tagetes, and Viola. HortScience 40:1336-1339.

Reich, P.B., D.S. Ellsworth, and M.B. Walters. 1998. Leaf structure (specific leaf area) modulates photosynthesis-nitrogen relations: Evidence from within and across species. Functional Ecology 12:948-958.

Styer, R.C. and D.S. Koranski. 1997. Plug and transplant production: A grower's guide. Ball Publishing, Batavia, IL.

USDA. 2010. Floriculture crops 2009 summary. Nat. Agr. Sta. Service, Washington, DC. 8 June 2010. <http://usda.mannlib.cornell.edu/usda/ current/FlorCrop/FlorCrop-06-04-2010.pdf>.

Wook, O., I.H. Cheon, K.S. Kim, and E.S. Runkle. 2009. Photosynthetic daily light integral influences flowering time and crop characteristics of Cyclamen persicum. HortScience 44:341-344. 